\title{
Progressive Paraplegia: Take A Closer Look
}

\section{Sajid Hameed*}

Neurology Resident, Aga Khan University Hospital, Pakistan

Submission: April 08,2019; Published: June 03, 2019

*Corresponding author: Sajid Hameed, Neurology Resident, Aga Khan University Hospital, Karachi, Pakistan

\section{Case Description}

A 69-year-old gentleman presented with a twelve-month history of progressive bilateral lower limb weakness and numbness. For the past two weeks, he developed constipation and urinary retention. He denied fever, backache, trauma, weight loss, or cough. For these symptoms, he had visited multiple doctors and had three Magnetic Resonance Imaging (MRI) of the spine, which were reported as cervical spondylosis, transverse myelitis, and syrinx, respectively. Still, his diagnosis was uncertain, and the weakness was gradually worsening. Medical history was significant for type 2 diabetes mellitus and hypertension. On examination, muscle strength was normal in upper limbs while it was reduced in the lower limbs bilaterally (MRC grade 3/5) with reduced deep tendon reflexes and upgoing plantar responses. All sensations were reduced below the level of T7. We repeated MRI of the spine. The T2-weighted images showed patchy edema in the spinal cord extending from C4 vertebral body up to the conus along with vessel flow voids dorsally (Figure 1), which were suggestive of Spinal Dural Arteriovenous Fistula (SDAVF). The diagnosis was subsequently confirmed on digital subtraction angiography and the fistula was embolized. He was stable post procedure and his weakness improved (MRC grade 4/5) within the next 48 hours.

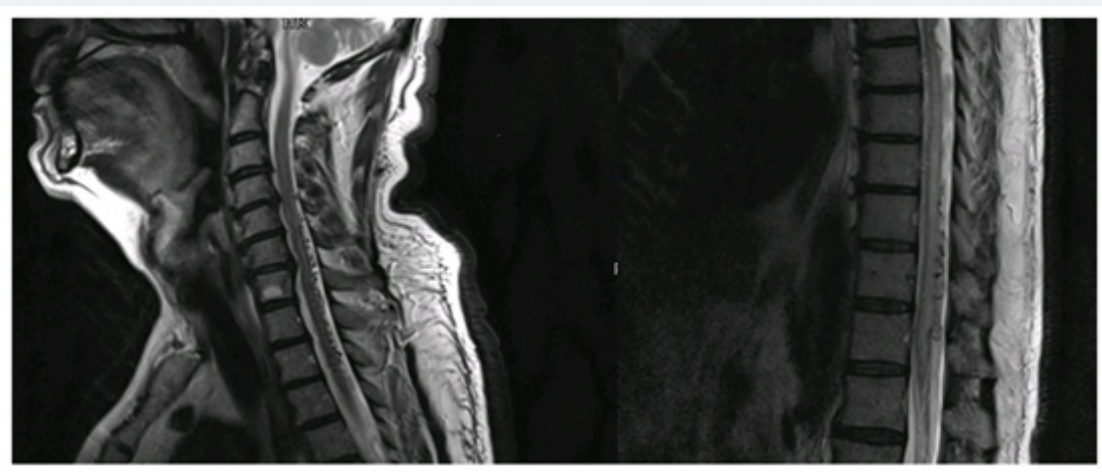

Figure 1: MRI spine sagittal T2-weighted images of the cervical spine (left) and lower thoracic spine (right).

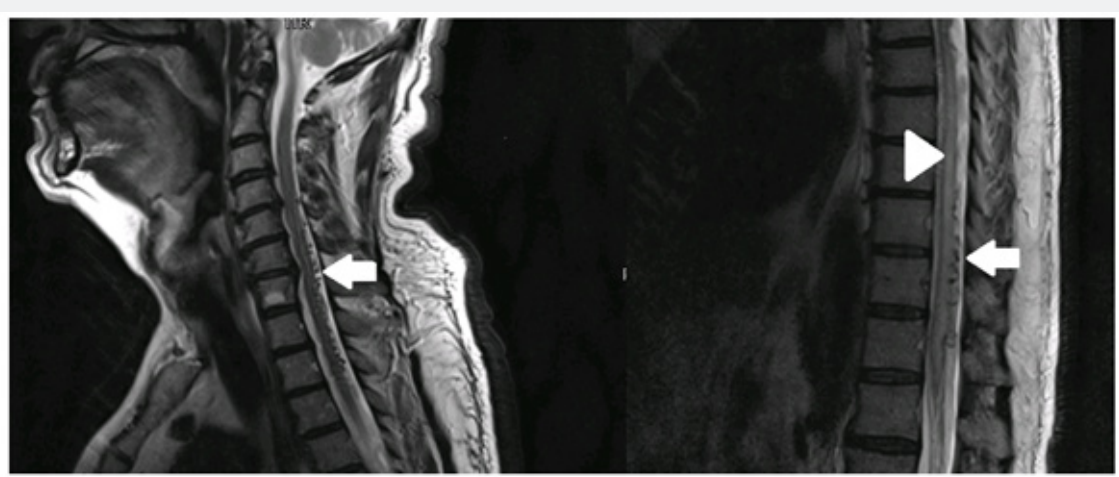

Figure 2: MRI spine sagittal T2-weighted images showing vessel flow voids dorsally (white arrows) and T2-hyperintense signals throughout the cord in the lower thoracic region (white arrowhead), suggestive of spinal Dural arteriovenous fistula. 
SDAVF is the most common vascular malformation of the spinal cord, albeit still rare, with an annual incidence of only 5-10 cases per million [1]. It is estimated that a neurologist sees a single case of SDAVF every 5 years. Diagnosis is often missed leading to diagnostic delay, as in our case. To our surprise, the literature reveals a delay of around 15-24 months from symptom-onset to the confirmation of the diagnosis of SDAVF $[2,3]$. Spinal MRI is often the first choice of investigation. It not only excludes the common causes of paraplegia but also reveals characteristic appearances suggestive of SDAVF. These include [1] T2 hyperintense signals within the cord, [2] spinal cord expansion, and [3] vessel flow voids on the dorsal and/or ventral aspect of the cord. (Figure 2). When these characteristic findings were missed on initial MRI spine and radiologist does not suspect vascular etiology, a mean diagnostic delay of 281 days is seen in the diagnosis of SDAVF from initial MRI as compared to only 22 days when a vascular etiology is suspected in the initial MRI reporting [4].

SDAVF has a variable prognosis but almost $90 \%$ of patients experience either stabilization or improvement in their symptoms following treatment [1]. The treatment involves either microsurgery or endovascular embolization to close the abnormal vascular connection. Since SDAVF is largely a reversible condition if diagnosed early, the neurologists and radiologists should be aware of the MRI findings to avoid misdiagnosis and unnecessary delays in the diagnosis [5].

\section{References}

1. Ma Y, Chen S, Peng C, Wang C, Li G, et al. (2018) Clinical outcomes and prognostic factors in patients with spinal dural arteriovenous fistulas: a prospective cohort study in two Chinese centres. BMJ open 8(1): e019800.

2. Cao W, Huang L, Ge L, Lu G, Zhang X, et al. (2014) A simple score (AVFS) to identify spinal dural arteriovenous fistula before spinal digital subtraction angiography. J Stroke Cerebrovasc Dis 23(8): 1995-2000.

3. Gemmete JJ, Chaudhary N, Elias AE, Toma AK, Pandey AS, et al. (2013) Spinal dural arteriovenous fistulas: clinical experience with endovascular treatment as a primary therapy at 2 academic referral centers. AJNR Am J Neuroradiol 34(10):1974-1949.

4. Hunt R, Roberts RM, Mortimer AM (2018) Spinal dural arteriovenous fistula: delay to radiological diagnosis and sources of radiological error. Clinical radiol 73(9): 835-e16.

5. Yen PP, Ritchie KC, Shankar JJ (2014) Spinal dural arteriovenous fistula: correlation between radiological and clinical findings. Journal of Neurosurgery Spine 21(5): 837-842.

\section{Your next submission with Juniper Publishers will reach you the below assets}

- Quality Editorial service

- Swift Peer Review

- Reprints availability

- E-prints Service

- Manuscript Podcast for convenient understanding

- Global attainment for your research

- Manuscript accessibility in different formats

( Pdf, E-pub, Full Text, Audio)

- Unceasing customer service

Track the below URL for one-step submission https://juniperpublishers.com/online-submission.php 